\title{
The Role of Supply Chain Integration and Agile Practices in Improving Lead Time During the COVID-19 Crisis
}

\author{
Haitham M. Alzoubi, Skyline University College, UAE \\ Hamzah Elrehail, Abu Dhabi School of Management, UAE \\ (iD https://orcid.org/0000-0001-6935-3355 \\ Jalal Rajeh Hanaysha, School of Business, Skyline University College, UAE \\ Anwar Al-Gasaymeh, Applied Science Private University, Jordan \\ Raid Al-Adaileh, Skyline University College, UAE
}

\begin{abstract}
Long lead time is hurting the competitiveness of the supply chain, while the shorter is considered to be better in order to add value to the customer and to improve the supply dependability. Supply chain integration increases the coordination and shortens the processes. Agile practices also enable the supply chain to be more responsive to market variability. The aim of this research is to investigate the impact of supply chain integration and agile practices on lead-time reduction at Dubai HealthCare City. An empirical survey has been conducted in which the data were retrieved from 150 respondents and then analyzed using SPSS to examine the model. The result also showed a positive relationship between supply chain integration and lead-time reduction. Meanwhile, results indicated a positive relationship between agile practices on lead-time reduction. The study recommends promoting companies' capabilities through flexibility and information sharing to achieve supply chain integration and agile practices such as responsiveness and alertness.
\end{abstract}

\section{KEYWORDS}

Agile Practices, Dubai Health Care, Lead-Time Reduction, Supply Chain

\section{INTRODUCTION}

In the current competitive and turbulent business landscape, requirements and demanding customers require companies to search for improving the order fulfilment process in an effective and efficient way to maintain superior performance, such as shorter order lead-time. Companies need to promote their resources in creative methods to develop their supply chain capabilities through supply chain coordination, collaboration, and agility, which would also enhance the performance and efficiency in lead-time (Alzoubi et al., 2019; Cheung et al., 2018).

Supply chain integration can be described as the process in which all parties engaged with the completion of a product are integrated into one unified system (Bianchini et al., 2019). Supply chain integration in healthcare services requires a high level of cooperation and coordination more than other industries and refers to the flow of materials, information, and money linked with on-time movement 
and attainment from the supplier to the end user, with prime emphasis on developed clinical outcomes and efforts optimization (Budacu \& Pocatilu, 2018). Agility, on the other hand, refers mainly to the organizational ability to capture the opportunities for competitive action and marshal the necessary resources to positively influence performance. An agile approach can promote new agile health practices and develop care processes to deliver more value and effectively adopt new technologies to develop the patient's care (Chang \& Lin, 2019).

Lead-time could be considered as the time between requesting and delivering the order or the amount of time required to satisfy the order fulfilment processes (Udokporo et al., 2020). In this context, lead-time reduction is the quantity of time that passes from the start of a procedure, such as manufacturing, supply chain management, project management till its completion (Mulugeta, 2017).

In essence, this study builds on a three-fold contribution to the existing body of literature. First, it proposes that supply chain integration could decrease the lead-time, which could lead to improving the supply chain performance as well as the satisfaction of the customers. Second, it proposes that agile practice could also decrease the lead-time by focusing on added value activities and eliminating unnecessary activities and blockages. Third, this study has been conducted during the COVID-19 crisis, where the need to reduce the lead time seems more important, especially within the context of the healthcare sector. Accordingly, this study seeks to explore and verify the impact of supply chain integration and agile practices on achieving lead-time reduction within the context of the healthcare sector of Dubai.

\section{THEORETICAL FRAMEWORK AND LITERATURE REVIEW}

\section{Supply Chain Integration}

Generally, supply chain integration could be described as all processes within an organisation that involve all suppliers and customers, integrating them to come up with a product or service (Malakouti et al., 2017). Meanwhile, supply chain refers to every input that is needed to produce a product or deliver a service and fulfil a certain need. Therefore, supply chain integration can be considered as a close alignment as well as coordination within a supply chain (Carvalho et al., 2012). It is often designed for the utilization of shared management information systems. Supply chain integration depends on its dimensions, such as strengths, duration, scope and depth. Each of these dimensions plays a crucial role in fulfilling the following processes (Ataseven \& Nair, 2017). Supply chain integration requires internal cooperation and external collaboration and also needs significant coordination as well as alignment to ensure that everyone is working effectively towards fulfilling the same goal (Yip, 2015). Integration related to the supply chain can be conceptualized by four dimensions, including strength, duration, scope and depth. All of these four dimensions are independent but need to be managed and integrated together (Budacu \& Pocatilu, 2018).

Supply chain integration could be divided into levels: internal supply chain integration and external supply chain integration. Internal integration is related to the active and on-time communication, coordination, cooperation and collaboration of inter- and cross-functional activities through systematic interaction within the supply chain (Dove, 2005). External integration is related to the interaction with suppliers, customers and other partners by ensuring continuous and fruitful communication, coordination and collaboration, creating a long-term partnership and strategic alliances (Christopher, 2000).

\section{Agile Practices}

Agile or agility in the supply chain means being alert and quick to respond. It could be viewed as being more flexible and more responsive to changes in the market requirements through information sharing along all supply chain parties and the ability to predict, detect and explore opportunities in the market and track them through innovative organizational learning (Gligor et al., 2015). Moreover, the design 
of the supply chain should consider the ability to be flexible and quick in response to uncertainty in the marketplace and the environment, in general (Gunasekaran \& Yusuf, 2002).

An agile method could be defined from different approaches; one specific approach is related to supply chain management, which is used to respond quickly and satisfy the market requirements (Kumar \& Bhatia, 2012). This method uses gradual, iterative work sequences that are generally known as sprints (Soares et al., 2019; Pantiuchina et al., 2017). This method specifically assists teams in case of responding to the contingency of constructing software. Significant variables related to agile practice are people (Baramichai et al., 2007), quality, functionality, tools, time, process, value and concept. All of these variables are considered as the fundamentals of agile practice (Bianchini et al., 2019).

\section{Lead-Time Reduction}

Lead-time is commonly perceived as an essential tool for measuring performance. Lead-time is the total amount of time that starts from order entry; this is the interval time between the customer's order and operations activities, including the material planning, administration, purchasing, transportation time and handling and storing time in inventory, warehousing preparation processes through paking and packaging, and finally the distribution and delivery to the customer (Lin, 2016).

Lead-time reduction is specifically designed to minimise the consumed time for completing a process from beginning to end. In case of any supply chain processes or service delivery, lead-time reduction defines the total time period to obtain and move the materials and get them ready to deliver to the consumers. Dimensions of lead-time reduction like pre-processing, manufacturing and postprocessing help to measure the overall quantity of time taken to complete the entire process (Fattahi et al., 2017). Lead-time reduction generally measures how much time it consumes to complete a procedure from start to end (Christensen et al., 2007). The dimensions related to lead-time reduction may include pre-processing, manufacturing and post-processing. On the basis of these dimensions, lead-time reduction is generally calculated by the organizations (Ciccullo et al., 2018).

Customers demand to know accurately the delivery time and management of supply chain needs to control all activities of lead-time. Trying to reduce the lead-time would enhance the productivity of the supply chain operations. That requires a concert supply chain planning, along with serious adherence to the schedule with a high level of coordination and flexibility, as well as on-time information sharing.

\section{Health Care Industry in Dubai:}

UAE, particularly Dubai, has appeared as the hub for medical tourism due to its world-class infrastructure and outstanding healthcare services throughout the Middle East and Gulf region. In consideration of many in-class hospitals as well as clinics, Dubai has also been known worldwide as the biggest medical free zone, particularly Dubai Healthcare City. The compound consists of 160 clinical partners, outpatient medical centres, hospitals, laboratories with licensed professionals from about 90 countries (Visitdubai, 2020; Dubai Healthcare Authority Report, 2019; Bakkar et al., 2018).

\section{Supply Chain Integration and Lead-Time Reduction}

Khan and Wisner (2019) stated that lead-time reduction is driven by numerous factors and parameter, which varies and impacts all supply chain parties and partners. Lead-time reduction uncertainty is considered as a type of supply uncertainty within the supply chain demand level of stability. Leadtime reduction management has been categorized within the physical functions of market mediations (Bianchini et al., 2019). As per the approach of supply chain integration, lead-time reduction is needed to be related to the market mediation activities. There are basically two uncertainties in the concept of supply chain integration (Fekpe \& Bray, 2015). The first one is related to internal integration in cross-functional activities, while the second one is related to external integration with suppliers and customer demand and its association with the lead-time reduction (Singh et al., 2013).

The uncertainty of lead-time reduction refers to the ambiguities within supply parties. Lead-time reduction requires the calculation of the time between initiating the order until finally delivering it. 
Lead-time reduction can be impacted negatively by a variety of factors, such as improper information systems and inefficient transportation (Mahajan \& Venugopal, 2012). These are considered controllable factors, while the uncontrollable influencing factors include sudden events or market changeability (Ward \& Zhou, 2006). All of these factors can cause or increase the uncertainties in lead-time reduction. Companies need to be alerted to these sorts of negative effects on the lead-time uncertainties, which directly impact the process of supply chain integration. Enhancing lead-time efficiency could be achieved by more coordination within the processes of supply chain activities (Chopra et al., 2004). Moreover, lead-time reduction is considered the major determinant that impacts planning within each phase of the supply chain (Treville et al., 2004). Based on the above, we can hypothesize the following:

H1: Supply chain integration has a significant impact on lead-time reduction at Dubai Healthcare City.

\section{Agile Practices and Lead-Time Reduction}

Udokporo et al., (2020) stated that a short lead-time is significant to have agile, quick and first move benefits and be capable of responding to rapid changes in current business markets. Agile practices are known as a development paradigm, which aims to be capable for responding quickly towards changes regarding the requirements of consumers (Tarafdar \& Qrunfleh, 2017). Lead-time reduction has been viewed as the efficient time period taken to process a particular order from the request until its delivery (Kumar et al., 2011). Agile practices within the supply chain activities and quick response to changeability in the marketplace is considered to be responsible for shortening the processes required until the delivery (Chan et al., 2009). The idea was majorly focused on being iterate, flexible, and work with stakeholders in order to create agile practices that would eliminate any waste or delay in the supply chain processes, and also needs to improve the predictability and control the uncertainty (Chan \& Kumar, 2009).

Agile practices are fundamentally related to assisting the supply chain in completing all required activities constantly in an attempt to develop the way they work with the purpose of delivering high-quality products or services (Petersen, 2010). Aligned to this, it could be stated that effective lead-time reduction possesses have a direct connection with agile practices. With the appropriate measurement of lead-time reduction, it would be easy to detect how long it would take to apply certain functionality (Mehralian et al., 2015). Without making any guess, accurate data can be gained with lead-time reduction measurement (Udokporo et al., 2020). Based on the above, we can hypothesize the following:

H2: Agile practices have a significant impact on lead-time reduction at Dubai Healthcare City.

\section{Research Model}

The research model can be reflected as a pictorial as well as a graphical representation of major concepts (Gutmann et al., 2016). Figure 1 below represents the research model and the hypotheses of the study.

\section{RESEARCH METHODOLOGY}

The design of this research followed the explanatory and descriptive methodology that examines and describes the relationships among the research variables. Meanwhile, the methodological approach considered in this research is quantitative in nature, which relies on collecting empirical data with the aid of the survey. This survey technique has been designed using the five-point Likert scale to measure the research variables. The entire process of data collection was conducted through an online survey. 


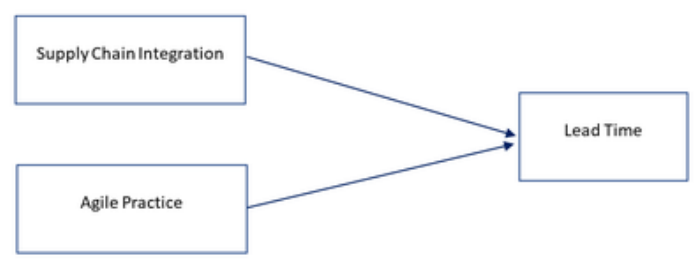

The population of this study involves employees of the Healthcare sector in Dubai, which consists of 38 hospitals, classified as follows: 6 government hospitals and 32 private hospitals (Dubai Healthcare Authority Report, 2019). 400 questionnaires were distributed, and 227 were retrieved. A total number of 150 valid questionnaires were used for the analysis, the response rate was $37.5 \%$, which is above the cut-off point of $30 \%$ for online surveys as recommended by (Fincham, 2008). The data of the participants' responses were collected and analysed in order to test the proposed relationships among the study variables.

The Content Validity of the questionnaire was reviewed and improved by a number of professionals and specialists in business management, and many of their suggestions improved the questionnaire. The results of Cronbach's Alpha of internal Consistency illustrate the reliability, as all values of Alpha in Table (1) were "high," which helps to give more understanding about how the questionnaire items are related to each other.

Table 1. Cronbach's alpha reliability

\begin{tabular}{|c|c|}
\hline study's variables & Cronbach's Alpha \\
\hline Supply chain integration & 0.914 \\
\hline Agile practices & 0.788 \\
\hline Lead-time reduction & 0.918 \\
\hline
\end{tabular}

\section{DATA ANALYSIS}

Through evaluating the responses or data by the participants, it can be stated that most of the respondents agreed with the impact of supply chain integration and agile practices on lead-time reduction. A descriptive statistic has been conducted to analyse the data more properly. Table (2) states the entire mean score of study variables, which are all above 3.66. This reflects high importance towards the availability of the study variables within the Dubai Healthcare City.

\section{Hypotheses Testing}

The analysis of results in Table $(3,4)$ showed the impact of supply chain integration and agile practices on lead-time reduction.

There is enough evidence from the statistical analysis, as shown in Table (3), that supply chain integration effect on lead-time reduction is proved by the value of $(\mathrm{r}=0.598)$, and supply chain integration is considered to be responsible (0.358) for the changes in lead-time reduction. The value of $(\mathrm{F}=19.632)$ confirms the validity of the construct. The value of $(\mathrm{t}=3.019)$ shows the impact of 
Table 2. Descriptive analysis of study variables

\begin{tabular}{|l|l|l|l|}
\hline \multicolumn{1}{|c|}{ Study Variables } & \multicolumn{1}{c|}{ Mean } & \multicolumn{1}{c|}{ Std. } & \multicolumn{1}{c|}{ Sig Rank } \\
\hline Supply chain integration & 3.78 & 0.99 & 2 - High \\
\hline Agile practices & 3.88 & 0.89 & 1 - High \\
\hline Lead-time reduction & 3.65 & 0.97 & 3 - High \\
\hline
\end{tabular}

Table 3. ANOVA analysis and regression analysis of supply chain integration in lead-time reduction

\begin{tabular}{|c|c|c|c|c|c|c|c|c|}
\hline Sig* & $\begin{array}{c}\text { Calculated } \\
\text { "t" }\end{array}$ & $\boldsymbol{\beta}$ & Sig* & DF & $\begin{array}{c}\text { Calculated } \\
\text { F }\end{array}$ & (r2) & (r) & \\
\hline \multirow{3}{*}{0.004} & \multirow{3}{*}{2.973} & \multirow{3}{*}{0.694} & \multirow{3}{*}{0.000} & 1 & \multirow{3}{*}{19.632} & \multirow{3}{*}{0.358} & \multirow{3}{*}{0.598} & \multirow{3}{*}{$\begin{array}{l}\text { Lead-time } \\
\text { reduction }\end{array}$} \\
\hline & & & & 149 & & & & \\
\hline & & & & 150 & & & & \\
\hline
\end{tabular}

${ }^{*}$ The impact is significant at level ( $\left.a £ 0.05\right)$

Table 4. ANOVA analysis and regression analysis of agile practices in lead-time reduction

\begin{tabular}{|c|c|c|c|c|c|c|c|c|}
\hline Sig* & $\begin{array}{c}\text { Calculated } \\
\text { "t"" }\end{array}$ & $\boldsymbol{\beta}$ & Sig* & DF & $\begin{array}{c}\text { Calculated } \\
\text { F }\end{array}$ & (r2) & (r) & \\
\hline \multirow{3}{*}{0.003} & \multirow{3}{*}{3.019} & \multirow{3}{*}{0.584} & \multirow{3}{*}{0.000} & 1 & \multirow{3}{*}{39.342} & \multirow{3}{*}{0.371} & \multirow{3}{*}{0.609} & \multirow{3}{*}{$\begin{array}{l}\text { Lead-time } \\
\text { reduction }\end{array}$} \\
\hline & & & & 149 & & & & \\
\hline & & & & 150 & & & & \\
\hline
\end{tabular}

* The impact is significant at level ( $a £ 0.05)$

supply chain integration on lead-time reduction at the significance of ( $\alpha £ 0.05)$. Therefore, we can support hypothesis 1 , which implies that supply chain integration impacts lead-time reduction. Whereas the statistical analysis provides evidence, as shown in Table (4), that agile practices related to lead-time reduction are proved by the value of $(\mathrm{r}=0.609)$, and agile practices are considered to be responsible ( 0.371$)$ for the changes in lead-time reduction. Moreover, the value of $(t=3.019)$ confirms the validity of the construct. The value of $(\mathrm{F}=39.342)$ shows that the impact of agile practices on lead-time reduction is significant at $(\alpha £ 0.05)$. Therefore, we can support hypothesis 2 , which implies that agile practices impact lead-time reduction.

\section{DISCUSSION}

From the overall results, it can be stated that the respondents at Dubai Healthcare City agreed that both processes of supply chain integration and agile practices contribute to lead-time reduction. Both supply chain integration and agile process are necessary in critical times to control any crisis, such as the current COVID-19. The results of analysis proved the positive relationship between Supply Chain Integration and lead-time reduction, as the correlation coefficient $(\mathrm{r}=0.598)$ and determination coefficient $(0.358)$ are positive, while the $(\beta=0.694)$ showed the validity of the impact that is already supported by $(\mathrm{F}=19.632)$ and $(\mathrm{t}=3.019)$. These results are also consistent with the findings of past research (Bianchini et al., 2019; Fekpe \& Bray, 2015; Singh et al., 2013; Mahajan \& Venugopal, 2012; Ward \& Zhou, 2006; Chopra et al., 2004; Treville et al., 2004). 
The results of the study also showed a positive relationship between agile supply chain practices and lead-time reduction, as the correlation coefficient $(\mathrm{r}=0.609)$ and determination coefficient $(0.371)$ are positive, while the $(\beta=0.584)$ showed the validity of the impact that is already approved by $(\mathrm{F}=39.342)$ and $(\mathrm{t}=3.019)$. These results are also consistent with the outcomes of prior research (Tarafdar \& Qrunfleh, 2017; Kumar et al., 2011; Chan et al., 2009; Chan \& Kumar, 2009; Mahto \& Kumar, 2008; Mason-Jones \& Towill, 1999). Moreover, results revealed that the agile practices contribute to reducing lead-time through agile inventory practices, eliminating losses, focusing on quality, process improvement, and reducing the less important processes in manufacturing, which will be eventually reflected in performance.

\section{IMPLICATION, CONCLUSION AND RECOMMENDATION}

The research aimed to examine the role of supply chain integration and agile practices to reduce the lead-time. It highlighted the relative contribution of the best implementation of supply chain integration as well as following the best agile practices. Subsequently, the goal of this research was the realization of the best optimization of the supply chain integration, aligned with the best agile practices, which would eventually lead to a reduction in supply chain lead-time by removing any processes or activities that don't add value to the supply chain operations. Furthermore, scalability of agile practice is related to lead-time reduction through improving its ability to respond to the market requirements rapidly-an empirical analysis of data from 150 participants working in the Dubai Healthcare City.

It could be recommended to the healthcare industry that it essentially required to arrange proper supply chain processes and implementation and adopt agile practice in teamwork with the aim of delivering services to the patient appropriately. Service organizations, such as healthcare organizations, are recommended to enhance their supply chain processes and integrate all of their activities and take any necessary strategy that eliminate the waste within its processes in order to reduce the lead-time, such as agile practices, especially in a crisis situation like COVID-19.

Companies could enhance the level of flexibility by focusing on the flexible supply chain strategy through sharing information and employing information technology and production technology throughout all supply chain parties to achieve a high degree of flexibility. Moreover, companies could emphasize speed in the delivery of orders and reliability in delivery through the selection of appropriate transportation, according to the nature of the products to reduce uncertainty through forecasting of demand and inventory control to achieve a high degree of response efficiency. Further implications could be seen through trying other methods that contribute to promoting the implementation of the agile supply chain strategy, including: Quality Management, Time Production System (JIT) and Production Flow Management in order to reduce costs and maintain the level of quality and reliability. 


\section{REFERENCES}

Abubakar, A. M. (2019). Using hybrid SEM - artificial intelligence: Approach to examine the nexus between boreout, generation, career, life and job satisfaction. Personnel Review, 49(1), 67-86. https://doi.org/10.1108/ PR-06-2017-0180

Abubakar, A. M., Behravesh, E., Rezapouraghdam, H., \& Yildiz, S. B. (2019). Applying artificial intelligence technique to predict knowledge hiding behavior. International Journal of Information Management, 49, 45-57.

Agarwal, R. (2020). Modified Ranking With Temporal Association Rule Mining in Supply Chains. International Journal of Service Science, Management, Engineering, and Technology, 11(4), 58-71.

Alzoubi, H., Ahmed, G., Al-Gasaymeh, A., \& Alkurdi, B. (2019). Empirical study on Sustainable Supply Chain Strategies and its impact on Competitive Priorities: The mediating role of Supply Chain Collaboration. Management Science Letters, 10(3), 703-708.

Alzoubi, H., \& Yanamandra, R. (2020). Investigating the mediating role of Information Sharing Strategy on Agile Supply Chain in Supply Chain Performance. Uncertain Supply Chain Management, 8(2), $273-284$. doi:10.5267/j.uscm.2019.12.004

Ataseven, C., \& Nair, A. (2017). Assessment of supply chain integration and performance relationships: A meta-analytic investigation of the literature. International Journal of Production Economics, 185(1), 1-48. doi:10.1016/j.ijpe.2017.01.007

Bakkar, M., Khelalfa, H. M., \& McKay, E. (2018). Perception of information systems security: Serving healthcare industry in Dubai. International Journal of Internet and Enterprise Management, 9(1), 58-89. doi:10.1504/ IJIEM.2018.098935

Baramichai, M., Zimmers, E. W. Jr, \& Marangos, C. A. (2007). Agile supply chain transformation matrix: An integrated tool for creating an agile enterprise. Supply Chain Management, 12(5), 334-348. doi:10.1108/13598540710776917

Bianchini, A., Benci, A., Pellegrini, M. \& Rossi, J. (2019). Supply chain redesign for lead-time reduction through Kraljic purchasing portfolio and AHP integration. Benchmarking: An international Journal, 26(4), 1194-1209. .10.1108/BIJ-07-2018-0222

Budacu, E.N., \& Pocatilu, P (2018). Real Time Agile Metrics for Measuring Team Performance. Informatica Economica, 22(4), 70-79. DOI:.10.12948/issn14531305/22.4.2018.06

Carvalho, H., Azevedo, S., \& Cruz-Machado, V. (2012). Agile and Resilient Approaches to Supply Chain Management: Influence on performance and Competitiveness. Logistics Research, 4(1-2), 49-62. doi:10.1007/ s12159-012-0064-2

Chan, F. T., \& Kumar, V. (2009). Performance optimization of a leagility inspired supply chain model: A CFGTSA algorithm based approach. International Journal of Production Research, 47(3), 777-799. doi:10.1080/00207540600844068

Chan, F. T., Kumar, V., \& Tiwari, M. K. (2009). The relevance of outsourcing and leagile strategies in performance optimization of an integrated process planning and scheduling model. International Journal of Production Research, 47(1), 119-142. doi:10.1080/00207540600818195

Chang, W. \& Lin., Y. (2019). The effect of lead-time on supply chain resilience performance. Asia Pacific Management Review, 24(4), 298-309. .10.1016/j.apmrv.2018.10.004

Cheung, W., Chiang, A. H., Sambamurthy, V., \& Setia, P. (2018). Lean vs. Agile Supply Chain: The Effect of IT Architectures on Supply Chain Capabilities and Performance. Pacific Asia Journal of the Association for Information Systems, 10(1), 106-121. doi:10.17705/1pais.10103

Chopra, S., Reinhardt, G., \& Dadahardt, M. (2004). The effect of lead time uncertainty on safety stocks. Decision Sciences, 35(1), 1-24. doi:10.1111/j.1540-5414.2004.02332.x

Christensen, W. J., Germain, R. N., \& Birou, L. (2007). Variance vs average: Supply chain lead-time as a predictor of financial performance. Supply Chain Management, 12(5), 349-357. doi:10.1108/13598540710776926 
Christopher, M. (2000). The agile supply chain: Competing in volatile markets. Industrial Marketing Management, 29(1), 37-44. doi:10.1016/S0019-8501(99)00110-8

Ciccullo, F., Pero, M., Caridi, M., Gosling, J., \& Purvis, L. (2018). Integrating the environmental and social sustainability pillars into the lean and agile supply chain management paradigms: A literature review and future research directions. Journal of Cleaner Production, 172(1), 2336-2350. doi:10.1016/j.jclepro.2017.11.176

Dove, R. (2005). Agile Enterprise Cornerstones: Knowledge, Values, and Response Ability. In IFIP International Working Conference on Business Agility and Information Technology Diffusion (pp. 313-330). Springer. doi:10.1007/0-387-25590-7_20

Dubai Healthcare Authority Report. (2019). Retrieved on June, 2020 from: https://www.dha.gov.ae/en/Pages/ Opendata.aspx

Fattahi, M., Govindan, K., \& Keyvanshokooh, E. (2017). Responsive and resilient supply chain network design under operational and disruption risks with delivery lead-time sensitive customers. Transportation Research Part E, Logistics and Transportation Review, 101(1), 176-200. doi:10.1016/j.tre.2017.02.004

Fekpe, E.S., \& Bray, A-V. (2015). Effects of supply chain integration on lead time in the retail industry in Ghana. Journal of Business and Management Dynamics, 5(1). 10.4102/jbmd.v5i1.21

Galli, B. J. (2018). A Research Study on How Project Management Can Help Improve Lean Six Sigma: A Proposed Approach. International Journal of Service Science, Management, Engineering, and Technology, 9(4), 1-25.

Galli, B. J. (2018). Risks related to lean six sigma deployment and sustainment risks: How project management can help. International Journal of Service Science, Management, Engineering, and Technology, 9(3), 82-105.

Gligor, D. M., Esmark, C. L., \& Holcomb, M. C. (2015). Performance outcomes of supply chain agility: When should you be agile? Journal of Operations Management, 33-34(1), 71-82. doi:10.1016/j.jom.2014.10.008

Gunasekaran, A., \& Yusuf, Y. Y. (2002). Agile manufacturing: A taxonomy of strategic and technological imperatives. International Journal of Production Research, 40(6), 1357-1385. doi:10.1080/00207540110118370

Gutmann, E., Barstad, I., Clark, M., Arnold, J., \& Rasmussen, R. (2016). The intermediate complexity atmospheric research model (ICAR). Journal of Hydrometeorology, 17(3), 160113112628008. doi:10.1175/JHM-D-15-0155.1

Kaya, B., Abubakar, A. M., Behravesh, E., Yildiz, H., \& Mert, I. S. (2020). Antecedents of innovative performance: Findings from PLS-SEM and fuzzy sets (fsQCA). Journal of Business Research, 114, 278-289.

Khan, H., \& Wisner, J. D. (2019). Supply chain integration, learning, and agility: Effects on performance. Operations and Supply Chain Management, 12(1), 14-23. doi:10.31387/oscm0360218

Kumar, V., Mishra, N., Chan, F. T. S., \& Verma, A. (2011). Managing warehousing in an agile supply chain environment: An F-AIS algorithm based approach. International Journal of Production Research, 49(21), 6407-6426. doi:10.1080/00207543.2010.528057

Kumar \& Bhatia, P. (2012). Impact of Agile Methodology on Software Development Process. International Journal of Computer Technology and Electronics Engineering, 2, 2249-6343.

Lin, H.J. (2016). Investing in lead-time variability reduction in a collaborative vendor-buyer supply chain model with stochastic lead time. Computers and Operations Research, 72(43), 1-26.

Mahajan, S. \& Venugopal, V. (2012). Value of Information Sharing and Lead Time Reduction in a Supply Chain with Autocorrelated Demand. Technology Operation Management, 2(1), 39-49. .10.1007/s13727-012-0004-z

Mahto, D., \& Kumar, A. (2008). Improvements in Product Quality and Productivity Through Pragmatic Analysis of Working Environment in Engineering Industries. ARISER, 4(2), 77-97.

Malakouti, M., Rezaei, S., \& Shahijan, M. K. (2017). Agile supply chain management (ASCM): A management decision-making approach. Asia Pacific Journal of Marketing and Logistics, 29(1), 171-182. doi:10.1108/ APJML-02-2016-0031

Mason-Jones, R., \& Towill, D. (1999). Total cycle time compression and the agile supply chain. International Journal of Production Economics, 62(1-2), 61-73. doi:10.1016/S0925-5273(98)00221-7 
Mehralian, G., Zarenezhad, F., \& Rajabzadeh Ghatari, A. (2015). Developing a model for an agile supply chain in pharmaceutical industry. International Journal of Pharmaceutical and Healthcare Marketing, 9(1), 74-91. doi:10.1108/IJPHM-09-2013-0050

Mohamed, E., \& Hassan, A. (2019). How Does Complexity Affect the Relationship Between Supply Chain Integration and Firm Performance?: A Conceptual Framework. International Journal of Service Science, Management, Engineering, and Technology, 10(2), 22-37.

Mulugeta, T. (2017). Effect Of Supply Chain Integration On Lead Time: The Case Of Ethio-Nippon Technical Company S. C. (Unpublished Master Thesis). Addis Ababa University, Ethiopia.

Pantiuchina, J., Mondini, M., Khanna, D., Wang, X. \& Abrahamsson, P. (2017). Are Software Startups Applying Agile Practices? The State of the Practice from a Large Survey. .10.1007/978-3-319-57633-6_11

Petersen, K. (2010). An Empirical Study of Lead-Times in Incremental and Agile Software Development. An Empirical Study of Lead-Times in Incremental and Agile Software Development., 6195, 345-356. Advance online publication. doi:10.1007/978-3-642-14347-2_30

Singh, R.J., Sohani, N. \& Marmat, H. (2013). Effect of Lean/JIT Practices and Supply Chain Integration on Lead Time Performance. Journal of Supply Chain Management Systems, 2(2), 37-41.

Sisodia, S., \& Agrawal, N. (2019). Examining Employability Skills for Healthcare Services in India: A Descriptive Literature Review. International Journal of Service Science, Management, Engineering, and Technology, 10(3), $63-79$

Soares, L., Silva, F., Machado, I., \& de Souza, R. M. (2019). Investigating Agile Practices in Software Startups. $.10 .1145 / 3350768.3350786$

Tarafdar, M., \& Qrunfleh, S. (2017). Agile supply chain strategy and supply chain performance: complementary roles of supply chain practices and information systems capability for agility. International Journal of Production Research, 55(4), 925-938. 10.1080/00207543.2016.1203079

Treville, S., Shapiro, R. D., \& Hameri, A. (2004). From supply chain to demand chain: The role of lead time reduction in improving demand chain performance. Journal of Operations Management, 21(6), 613-627. doi:10.1016/j.jom.2003.10.001

Udokporo, C. K., Anosike, A., Lim, M., Nadeem, S. P., Garza-Reyes, J. A., \& Ogbuka, C. P. (2020). Impact of Lean, Agile and Green (LAG) on business competitiveness: An empirical study of fast moving consumer goods businesses. Resources, Conservation and Recycling, 156(1), 104714.

visitdubai. (2020). Healthcare \& pharma a healthy us $\$ 71.3$ billion industry by 2020. Retrieved from visitdubai: https://www.visitdubai.com/en/business-in-dubai/healthcare-and-pharma

Ward, P., \& Zhou, H. (2006). Impact of Information Technology Integration and Lean/Just-In-Time Practices on Lead-Time Performance. Decision Sciences, 37(2), 177-203.

Wipulanusat, W., Panuwatwanich, K., Stewart, R. A., Arnold, S. L., \& Wang, J. (2020). Bayesian network revealing pathways to workplace innovation and career satisfaction in the public service. Journal of Management Analytics, 1-28.

Yip, N. S. M. S. (2015). The Effect of Cyber Supply Chain Security Towards Lean and Agile Supply Chain Performance in Healthcare Industry: The Mediating Effect of Organizational Capabilities (Unpublished Doctoral dissertation). Universiti Sains Malaysia. Retrieved from: https:/core.ac.uk/download/pdf/78388862.pdf 
Haitham Muhammad Musa Alzoubi has been in the academic field since 2002. He holds a PhD in Management. His research interests lie in the area of Operations Management, Quantitative Management, Supply Chain Management, Human Resource and Information Systems as well as E-Supply Chain Management ranging from theory to design and implementation. In recent years, he has focused on better techniques for analysis and artificial intelligence to support supply chain networks. He has published around fifteen research papers and attended various conferences and academic committees as well. Haitham authored seven books and attended various training courses. Haitham has professional experience as Human Resources Consultant in big companies for the last six years.

Hamzah Elrehail serves as an Assistant Professor of Management at Abu Dhabi School of Management, Abu Dhabi, United Arab Emirates. His research spans into Leadership, HRM, Innovation management, Knowledge management and Strategy. He published several papers in ISI and Scopus indexed journals such as Computers in Human Behaviour, Telematics and Informatics, Journal of Workplace Learning, Journal of Information Technology, Journal of Innovation \& Knowledge and Journal of Intellectual Capital.

Jalal Rajeh Mohammad Hanaysha is currently an Assistant Professor at Skyline University College. He obtained his Ph.D. majoring in Management (Marketing) from Universiti Utara Malaysia, Malaysia, in 2015, as well as an MSc (Management) from Universiti Utara Malaysia in 2011. He also obtained his Bachelor's degree in Marketing from Arab American University in Palestine in 2008. Dr. Hanaysha has published many articles in the field of management and marketing and presented his research at several international conferences. His research interests include business management and marketing, in particular, branding, consumer behavior, social media marketing, CSR, business and product innovation, human resource practices, and business strategy. Dr. Hanaysha can be reached at jalal.hanayshi@yahoo.com.

Anwar Al-Gasaymeh is an academic career, specializing in Economics (Banking \& Finance and International Finance). His Master's degree was obtained from University Putra Malaysia and his PhD from the National University Malaysia. His MSc and PhD were concerned with International Finance and Banking and Finance. Furthermore, he has presented papers at more than five international conferences in Malaysia and United Arab Emirates. During the last few years he has published about fifteen papers in Scopus, Australian Business Deans Council (ABDC) Journals and Elsevier in the field of Economics, Islamic and conventional banking, and Purchasing Power Parity.

Raid Al-Adaileh is a professor of Business/Management Information Systems at Skyline University College. His research areas cover different disciplines including Knowledge Management, Learning Organizations, Strategic Management, and Strategic Diffusion of Information Technology. In addition to his academic interests, he worked in different managerial positions including the Vice Dean of the Faculty of Business at Mutah University (Jordan), the Head of Quality Assurance, Head of Business Department, Head of MIS Department at Mutah University and Prince Sultan College for Tourism and Business- Al-Faisal University (Saudi Arabia). Dr. Raid has a list of publications in books, international journals, conferences, and book reviews. He also served as former member of the editorial board of the Science Publishing Group Journal (Journal of Investment and Management), former member of editorial board of International Research Journal of Business and Social Sciences (IRJBSS), former member of Asian Academy of Management, former member of the Board of Advisors, Centre of Excellence for Scientific \& Research Journals, member of editorial board of Asian Economic and Financial Review, former member of E-learning committee - Mutah University, former member of Strategy Development committee - Mutah University and former member of the Academic Development Committee-Mutah University. 